\title{
PENGARUH RASIO CAMEL DAN FAKTOR MAKROEKONOMI TERHADAP KONDISI FINANCIAL DISTRESS PADA BANK BUSN NON DEVISA TAHUN 2014- 2019
}

\author{
Wella Wahyu Qur'anna \\ Universitas Negeri Surabaya \\ wella.17080574005@mhs.unesa.ac.id \\ Yuyun Isbanah \\ Universitas Negeri Surabaya \\ yuyunisbanah@unesa.ac.id
}

\begin{abstract}
The bank, as financial intermediaries, is institutions that collect funds from society and distribute those funds for credit and providing other banking services. So, banking health is essential to prevent banks from Financial distress that leads to bankruptcy. This study analyses the effect of the CAMEL ratio and macroeconomic factors to predict non-foreign exchange bank is in 2014-2019 Financial distress. The CAMEL ratio consists of Capital proxied by CAR (Capital Adequacy Ratio), Asset Quality proxied by NPL (Non-Performing Loan), Management proxied by BOPO (Operating Expense to Operations Income), Earning proxied by ROA (Return on Asset), Liquidity proxied by LDR (Loan to Deposit Ratio). Then, macroeconomic factors proxied by GDP (Gross Domestic Product) and Inflation. This study used 20 non-foreign exchange bank is in 2014-2019 as the sample was determined using purposive sampling, and the statistical methods used to analyze is logistic regression in SPSS 25. This study shows that CAR, NPL, BOPO, LDR, GDP and Inflation have no significant effect on the probability of a bank's financial distress. On the other hand, ROA has a significant effect on the probability of a bank's financial distress.
\end{abstract}

Keywords: CAMEL ratio; financial distress; macroeconomic factors; non-foreign exchange bank

\section{PENDAHULUAN}

Era modern dan serba cepat seperti saat ini banyak aktivitas atau kegiatan setiap orang yang selalu melibatkan atau berkaitan dengan sektor perbankan. Anggapan dari setiap orang bahwa bank berkaitan dengan uang, karena bank merupakan lembaga keuangan. Bank sendiri memberikan fasilitas berbagai jasa keuangan, pada dasarnya bank adalah suatu lembaga yang mengatur keuangan dalam pelaksanaan utamanya merupakan menyimpan dana dari masyarakat serta mendistribusikan kembali dana tersebut pada masyarakat, dan bank juga melayani jasa yang lain. Kasmir (2014) mengemukakan berbagai jasa yang ditawarkan tergantung dari kemampuan setiap bank, semakin beragam produk yang ditawarkan semakin mampu bank tersebut baik pada segi menejemen permodalan, fasilitas sarana serta prasarana.

Resiko yang mungkin terjadi pada bank, apabila tidak dikelola dengan baik dapat menganggu stabilitas bank bahkan dapat berpotensi berpengaruh terhadap kesehatan bank. Bank yang tidak mampu mengelola resiko dengan baik dapat menyebabkan bank mengalami kondisi financial distress (Kasmir, 2014). Menurut Andari \& Wiksuana (2017), financial distress merupakan keadaan lembaga keuangan atau perbankan yang mengalami kesulitan keuangan, sebelum mengalami suatu kebangkrutan. Ketika berada pada kondisi ini bank harus mengambil langkah yang tepat, apabila tidak tepat dalam penanganannya dapat berakibat bank tersebut mengalami kebangkrutan serta bank mengharuskan untuk mengambil langkah dilikuidasi. Kondisi bank yang mengalami financial distress akan membuat investor mengalami kerugian. Selain itu, juga dapat memengaruhi perekonomian dalam suatu negara. Sangat perlu untuk mendeteksi lebih dini jika bank menghadapi terjadinya financial distress. Selayaknya lembaga perbankan perlu menganalisis kondisi keuangannya, agar mengetahui kondisi bank tersebut entah pada kondisi sehat, kurang sehat, atau mengalami kondisi sakit. Setiap keadaan yang dialami oleh lembaga keuangan memiliki penanganan masing-masing (Santoso, 2017). 
Wella Wahyu Qur'anna \& Yuyun Isbanah. Pengaruh Rasio Camel dan Faktor Makroekonomi terhadap Kondisi Financial Distress pada Bank Busn Non Devisa tahun 2014-2019

Maharani (2018), mengemukakan financial distress sebagai kondisi perusahaan yang mengalami defisit keuangan pada beberapa tahun terakhir secara beruntun. Laba bersih dari laporan keuangan perusahaan menjadi indikator kinerja suatu bank. Sehingga, kinerja suatu bank adalah pedoman untuk hal-hal yang perlu diperbaiki seterusnya dengan cara yang tepat dan sesuai. Upaya dalam mengukur kesehatan bank dapat menggunakan perhitungan CAMEL. Penilaian dengan analisa CAMEL menggunakan beberapa unsur yaitu permodalan, kualitas aset, manajemen, rentabilitas, dan likuiditas (Kasmir, 2014).

Sitanggang (2018), berdasarkan perolehan analisis statistik perbankan Indonesia (SPI) yang diterbitkan Otoritas Jasa Keuangan (OJK) Mei 2018, Loan to Deposit Ratio (LDR) pada Bank Pembangunan Daerah (BPD) masih pada level 77,74\%. Meski secara tahunan LDR tersebut naik dari 72,9\% Mei 2017, namun dibandingkan dengan bank lain posisi ini masih terbilang rendah. BUSN non devisa yang saat ini memiliki posisi LDR di level 92,39\%, BUSN devisa 87,2\%, Bank Persero 93,82\% Mei 2018. Sementara secara industri perbankan, saat ini LDR berada di posisi $92 \%$ atau meningkat dibandingkan Mei 2017 sebesar 88,57\%.

Otoritas Jasa Keuangan (2016), menyebutkan bahwa tahun 2013 sampai 2016 lembaga keuangan mengalami peningkatan kredit serta penghimpunan dana pihak ketiga yang bermasalah. Pertumbuhan kredit melambat disebabkan oleh keadaan ekonomi domestik yang belum stabil dan diiringi kurangnya permintaan terhadap jasa dan barang. Sedangkan penghimpun dana pihak ketiga bermasalah karena dampak kebijakan suku bunga acuan Bank Indonesia yang menyebabkan penurunan suku bunga simpanan. Sedangkan pada kredit bermasalah perbankan justru mengalami kenaikan tahun 2013-2016. Pada akhir 2013, NPL perbankan sebesar 1,7\%, tetapi bulan September 2016, sebesar 3,1\%. Melambatnya perekonomian domestik adalah efek aktivitas ekonomi dunia, harga minyak mentah yang turun serta komoditas yang lain, dan adanya larangan ekspor hasil tambang yang berdampak pada NPL perbankan hingga di atas 3\% pada 2016.

Anggraini (2019), mengemukakan tahun 2016-2017 pertumbuhan fintech di Indonesia mengalami peningkatan menjadi 78\% atau sebanyak 135 - 140 perusahaan yang sebelumnya tahun 2006-2007 hanya tumbuh 7\%. Hadad (2017) mengemukakan Di Indonesia pelaku fintech dominan berbisnis pada segmen Payment (43\%), Lending (17,78\%), dan sisanya seperti Agregator (12,59\%), Crowdfunding $(8,15 \%)$, dan lain-lain. Fitra (2019) mengemukakan perbankan tidak menganggap fintech sebagai ancaman atau lawan melainkan merangkul perusahaan fintech sebagai partner, meskipun dianggap bukan ancaman atau lawan tetap saja kehadiran layanan digital milik perusahaan fintech dapat menganggu sumber penghasilan bank karena sebelum adanya perusahaan fintech transaksi non-tunai lebih condong memakai fasilitas dompet digital pada bank layaknya kartu debet, kredit, dan real time gross settlement (RTGTS). Selain terdapat kredit bermasalah dalam lembaga keuangan nasional yang mengalami peningkatan juga terdapat peningkatan pertumbuhan fintech.

Fakta tersebut mendukung untuk dilakukan analisis terhadap perbankan karena terjadinya kredit bermasalah yang meningkat dan persaingan antar bank yang ketat sejalan dengan turunnya sumber penghasilan bank. Apabila tidak ditangani dengan bijak tentunya akan mengganggu stabilitas sistem keuangan yang disebut financial distress yang dapat berujung pada kebangkrutan. Kondisi financial distress ditunjukkan bila perbankan menghasilkan laba negatif dua tahun berturut-turut (Maharani : 2018) . Kondisi ini ditemukan pada beberapa Bank BUSN non devisa periode 2014 sampai 2019 terdapat beberapa bank yang menderita financial distress. Bank BUSN non devisa yang menderita financial distress diantaranya yaitu Oke Bank tahun 2014 hingga 2016 (Oke Bank Indonesia, 2020), Bank Artos Indonesia tahun 2016 hingga 2019 (Bank Artos, 2020), dan Bank Harda Internasional tahun 2019 (Bank Harda Internasional, 2019).

Salah satu alat untuk mengukur kesehatan bank menggunakan analisis CAMEL (Kasmir, 2014). Indikator rasio CAMEL diantaranya yaitu variabel permodalan yang diproksikan dengan CAR berdasarkan penelitian Ramadhani (2019), CAR berpengaruh positif terhadap kondisi financial distress pada bank, di mana semakin tinggi CAR maka semakin tinggi potensi financial distress. Sebaliknya, menurut Sadida (2018) CAR berpengaruh negatif signifikan terhadap financial distress di 
mana semakin tinggi CAR maka semakin kecil potensi financial distress. Berbeda dengan penelitian Aminah (2019) CAR tidak berpengaruh signifikan terhadap financial distress pada bank. Variabel kualitas asset yang diproksikan dengan NPL, menurut Ismawati \& Istria (2015) NPL berpengaruh positif signifikan terhadap probabilitas financial distress. Andari \& Wiksuana (2017) mengemukakan NPL berpengaruh negatif terhadap financial distress. Sebaliknya, Theodorus \& Artini (2018) menyatakan bahwa NPL tidak berpengaruh terhadap probabilitas financial distress. Selanjutnya, variabel manajemen yang diproksikan dengan BOPO pada penelitian Kurniasari \& Ghozali (2013) berpengaruh positif signifikan terhadap financial distress. Sedangkan, Africa (2018) mengemukakan BOPO tidak berpengaruh signifikan terhadap financial distress.

Indikator rentabilitas yang diproksikan oleh ROA, menurut Iswanto (2018) ROA berpengaruh positif signifikan terhadap financial distress. Sebaliknya, Nufus (2018) mengemukakan ROA berpengaruh negatif signifikan terhadap financial distress. Sedangkan, Musdholifah (2020) menyatakan bahwa ROA tidak berpengaruh terhadap financial distress. Variabel likuiditas yang diproksikan dengan LDR, penelitian oleh Caggiano (2014) LDR berpengaruh positif signifikan terhadap financial distress. Sebaliknya, penelitian Baselga-Pascual (2015) LDR berpengaruh negatif signifikan terhadap financial distress. Sedangkan, menurut Africa (2018) LDR tidak berpengaruh signifikan terhadap financial distress.

Selain faktor internal bank, kondisi kesehatan bank dapat dipengaruhi oleh faktor eksternal bank seperti faktor pertumbuhan ekonomi (GDP) dan terjadinya inflasi pada suatu negara. Pertumbuhan ekonomi yang diproksikan dengan Gross Domestic Product (GDP) berpengaruh negatif signifikan terhadap financial distress (Caggiano dkk., 2014). Sedangkan, penelitian Prianti (2018) dan Febriana (2019) menunjukkan hasil GDP tidak berpengaruh. Inflasi memiliki hubungan yang negatif di mana semakin kecil tingkat inflasi di suatu negara maka semakin tinggi kemungkinan terjadinya financial distress pada bank (Baselga-Pascual et al., 2015). Sebaliknya, Febriana (2019) mengemukakan inflasi tidak berpengaruh signifikan terhadap financial distress pada bank. Berdasarkan hasil uraian tersebut masih terdapat perbedaan dan hasil yang tidak konsisten (research gap) sehingga penelitian ini bertujuan untuk menganalisis pengaruh Rasio CAMEL (CAR, NPL, BOPO, ROA, LDR) dan faktor makroekonomi (GDP dan Inflasi) pada BUSN non devisa tahun 20142019 yang mengalami financial distress. Diharapkan hasil dari penelitian ini dapat menjadi penunjang oleh pihak yang memerlukan sebagai pertimbangan untuk membuat keputusan serta menjadi kajian pustaka tentang keadaan bank yang mengalami financial distress.

\section{KAJIAN PUSTAKA DAN PENGEMBANGAN HIPOTESIS}

\section{Financial distress}

Rodoni (2014), financial distress merupakan suatu perusahaan mengalami penurunan laba bersih operasi (net operating income negatif) dan tidak membayar deviden pada. Financial distress menjadi indikator dalam lembaga keuangan yang mengalami delisted karena laba bersih serta nilai buku ekuitas negatif secara terus-menerus sehingga dilakukan demerger. Perusahaan dalam 2 tahun terakhir mengalami laba bersih (net income) negatif dan nilai buku ekuitas negatif secara terus menerus dikatakan menderita financial distress. Financial distress diukur dengan melihat laba bersih negatif minimal dua tahun berturut-turut kemudian diklasifikasikan menggunakan metode dummy, 0 untuk bank tidak menderita dan 1 untuk bank yang menderita financial distress ((Kurniasari \& Ghozali, 2013).

Amalia \& Mardani (2018), penyebab financial distress ada dua faktor diantaranya faktor internal dan eksternal, faktor internal yaitu kurangnya biaya operasional dan ketidakmampuan perusahaan dalam membayar kewajibannya. Sedangkan faktor eksternal adalah kebijakan yang dibuat oleh pemerintah seperti peningkatan pajak atau terjadi krisis pada suatu negara. Faktor-faktor tersebut dapat menyebabkan perusahaan mengalami kesulitan keuangan sehingga dapat mendorong terjadinya kebangkrutan. 
Wella Wahyu Qur'anna \& Yuyun Isbanah. Pengaruh Rasio Camel dan Faktor Makroekonomi terhadap Kondisi Financial Distress pada Bank Busn Non Devisa tahun 2014-2019

Pendekatan untuk mengukur financial distress pada bank adalah menggunakan rasio CAMEL. Rasio CAMEL berguna dalam menilai kondisi kesehatan bank, karena dinilai mampu untuk melihat keadaan bank apabila menderita financial distress. Terdapat lima komponen yang dihitung dalam Rasio CAMEL yaitu permodalan, kualitas aset, manajemen, rentabilitas serta likuiditas. Selain itu, faktor makroekonomi seperti GDP/PDB dan Inflasi pada suatu negara juga dianggap berpengaruh terhadap terjadinya kesulitan keuangan pada bank (financial distress).

Sebagai variabel dependen, financial distress akan dianalisis menggunakan logistic regression dengan persamaan logistic regression pada persamaan (1) dan (2).

$Y=\operatorname{Ln} \frac{p}{1-p}=b 0+b 1 C A R+b 2 N P L+b 3 B O P O+b 4 R O A+b 5 L D R+b 6 G D P+$ $b 7$ Inflasi $+e$.

$Y=\operatorname{Ln} \frac{p(\text { tidak bermasalh })}{1-p(\text { bermasalah })}=$ financial distress

$\mathrm{b} 0=$ konstanta

$\mathrm{b} 1, \ldots, \mathrm{b} 7=$ koefisien regresi

CAR = Capital Adequacy Ratio

NPL $=$ Non Performing Loan

BOPO = Biaya Operasional Terhadap Pendapatan Operasional

ROA $=$ Return on Assets

LDR = Loan to Deposit Ratio

GDP $=$ Gross Domestic Product

\section{Teori Krisis}

\section{Model Generasi Pertama}

Model generasi pertama diperkenalkan oleh Paul (1979), bahwa terjadinya krisis keuangan dapat dikaitkan dengan permasalahan fiskal, moneter, anggaran pemerintah suatu negara yang defisit dan sistem nilai tukar yang cenderung stabil. Hal tersebut menjelaskan bahwa krisis finansial merupakan akibat kesalahan pemerintah suatu negara dalam mengelola perekonomian negara. Musdholifah (2020), mengemukakan model generasi pertama dapat ditinjau dari tingkat defisit anggaran negara yang besar, dengan tingginya pertumbuhan jumlah uang yang beredar, dan berkurangnya cadangan devisa negara, tingginya tingkat inflasi serta nilai mata uang domestik mengalami overvalued.

\section{Model Generasi Kedua}

Pertama kali model generasi kedua dijelaskan oleh Obstfeld (1984), model generasi kedua sering disebut proses self-fulfilling. Proses self-fulfilling adalah nasabah yang merasa khawatir karena tidak mengetahui cara bank mengelola keuangan atau adanya peristiwa acak dari berita, hal tersebut menyebabkan bank runs. Meskipun, keadaan perekonomian tidak mengalami guncangan namun dapat menyebabkan krisis yang merupakan akibat dari kurangnya likuiditas. Model generasi kedua memiliki kekurangan yaitu tidak dapat digunakan memprediksi sebab dan kapan krisis terjadi karena berdasarkan peristiwa acak yang mengubah harapan secara tiba-tiba atau mendadak.

\section{Model Generasi Ketiga}

Model generasi ketiga adalah keterkaitan dari sektor perbankan, korporasi, serta perkembangan faktor makroekonomi pemerintah atau Asian Crisis. Model generasi ketiga menekankan penjaminan pada pemerintahan yang akan memberikan sejumlah dana kepada bank yang menderita permasalahan dan perusahaan swasta lalu mencarikan pendapatan investor pada waktu yang akan datang, hal ini disebut dengan peran moran hazard (Prianti, 2018). Menurut Rosita \& Musdholifah (2018), metode generasi ketiga perlu pengawasan kepada sektor perbankan dalam mencegah financial distress.

\section{Permodalan (Capital)}

Kasmir (2014), mengemukakan penilaian menggunakan teknik CAR (Capital Adequacy Ratio), yang dibandingkan dengan modal terhadap aktiva tertimbang menurut resiko (ATMR). Teknik CAR 
mengidentifikasi aset perbankan yang turun serta masih bisa dikendalikan oleh ekuitas bank yang ada (Andari \& Wiksuana, 2017). Berdasarkan Surat Edaran Bank Indonesia No. 6/23/DPNP Tahun 2004 bank dikatakan dalam kondisi yang sehat jika memiliki minimal tingkat CAR $8 \%$, lalu bank yang mengalami kondisi tidak sehat jika tingkat CAR menghasilkan nilai kurang dari 8\%. Rumus dalam menghitung CAR menurut Kasmir (2014) pada persamaan (3).

$C A R=\frac{\text { Modal Bank }}{A T M R} \times 100 \%$

\section{Kualitas Aset (Asset Quality)}

Kurniasari \& Ghozali (2013), mengemukakan NPL digunakan untuk melihat tingkat kredit bermasalah dari bank melalui total kredit. Iswanto (2018), tingkat NPL yang tinggi maka probabilitas kebangkrutan bank juga akan meningkat. Berdasarkan Surat Edaran Bank Indonesia No. 6/23/DPNP Tahun 2004 suatu bank dikatakan sehat apabila menghasilkan nilai NPL kurang dari 6\% dan apabila memiliki NPL lebih dari 6\% dapat dikategorikan bank dalam kondisi tidak sehat. Rumus yang digunakan dalam perhitungan NPL menurut (Kasmir, 2014) pada persamaan (4).

$N P L=\frac{\text { Kredit Bermasalah }}{\text { Total Kredit }} \times 100 \%$.

\section{Manajemen (Management)}

Manajemen diproksikan dengan BOPO, rasio yang digunakan untuk menilai beban operasional yang dibandingkan pendapatan operasional merupakan teknik perhitungan BOPO (Kasmir, 2014). Menurut Nugroho (2012), rasio efesiensi digunakan untuk mengukur kesanggupan manajemen bank dalam mengendalikan biaya operasional kepada pendapatan operasional. Biaya yang keluar dalam menjalankan usaha pokoknya (biaya tenaga kerja, pemasaran, bunga, dan sebagainya) oleh bank adalah biaya operasional. Menurut Kasmir (2014) rumus BOPO pada persamaan (5).

$$
\text { BOPO }=\frac{\text { Total Biaya Operasional }}{\text { Total Pendapatan Operasional }} \times 100 \%
$$

\section{Rentabilitas (Earning)}

Kasmir (2014), mengemukakan cara menilai tingkat rentabilitas pada bank yang dilihat dari kesanggupan bank untuk menghasilkan keuntungan. Cara menilai pada variabel ini bisa dilihat dua jenis, yaitu rasio beban operasional terhadap pendapatan operasional (BOPO), serta rasio laba yang diambil dari total aset (Return on Assets), tetapi pada penelitian ini diproksikan dengan ROA (Return on Assets). Cara menghitung ROA menggunakan rumus dari penelitian Siregar \& Fauzie (2012) pada persamaan (6).

$R O A=\frac{\text { Laba sebelum pajak }}{\text { Total aset }} \times 100 \%$

\section{Likuiditas (Liquidity)}

Loan to Deposit Ratio (LDR) adalah proksi dari hasil perhitungan likuiditas menghasilkan nilai kesehatan bank dari Rasio CAMEL. Dalam menilai komposisi jumlah kredit yang sudah bank berikan dibandingkan dengan total dana yang ada di pihak ketiga menggunakan LDR (Prasidha, 2015). Rumus (7) digunakan untuk mengitung LDR menurut Prasidha (2015).

$$
L D R=\frac{\text { Total Kredit }}{\text { Total Dana Pihak Ketiga }} \times 100 \%
$$

\section{Pertumbuhan Ekonomi (Gross Domestic Product)}

Letarisky (2014), mendefinisikan GDP (Gross Domestic Product) sebagai nilai suatu produk yang diproduksi pada suatu negara, baik yang dilaksanakan warga negara maupun warga negara asing yang bekerja di wilayah tersebut. GDP merupakan ukuran nilai jasa serta barang yang dihasilkan pada negara tersebut pada kurun waktu tertentu, baik warga negara yang menduduki wilayah tersebut maupun warga negara asing yang bekerja di negara tersebut. Rumus (8) digunakan menghitung GDP menurut Letarisky (2014). 
Wella Wahyu Qur'anna \& Yuyun Isbanah. Pengaruh Rasio Camel dan Faktor Makroekonomi terhadap Kondisi Financial Distress pada Bank Busn Non Devisa tahun 2014-2019

$G D P$ riil $=\frac{G D P_{t}-G D P_{t-1}}{G D P_{t-1}} \times 100 \%$

\section{Inflasi}

Waluyo \& Yulianti (2016), inflasi diartikan nilai harga yang naik secara terus-menerus yang memengaruhi individu-individu,bisnis, dan pemerintah yang disebabkan oleh beberapa hal seperti Penetapan peraturan pemerintah yang bersifat ekonomi maupun non ekonomi akan menyebabkan terjadinya kenaikan harga, terdapat pengaruh alam yang bisa berpengaruh terhadap proses membuat serta kenaikan harga, timbulnya penawaran secara berlebihan akan menyebabkan permintaan barang serta jasa lebih cepat untuk, dan pengaruh inflasi luar negeri. Rodoni (2014), cara untuk mengetahui tingkat inflasi dengan persamaan (9).

$I t=\frac{C P I_{1}-C P I_{t-1}}{C P I_{t-1}}$.

\section{Pengaruh Antar Variabel}

Kurniasari \& Ghozali (2013), mengemukakan pentingnya variabel permodalan untuk memperkirakan tingkat kesehatan bank dan pengembangan usaha. Hal tersebut, agar kepercayaan masyarakat terhadap lembaga keuangan, melakukan proteksi terhadap dana dari masyarakat yang sudah dipercayakan pada perbankan dan memenuhi ketentuan yang telah ditetapkan oleh Bank Indonesia. Modal yang digunakan bank bertujuan untuk keperluan kegiatan operasional bank dan memenuhi seluruh kebutuhan bank untuk menghasilkan laba yang sudah ditetapkan. Sadida (2018), CAR dapat digunakan untuk memprediksi kesulitan keuangan, karena modal adalah komponen yang sangat penting untuk menutupi resiko kerugian yang bisa saja muncul akibat dari dana yang ditanamkan dalam asset yang potensial terdapat resiko dan belum dapat dimanfaatkan dalam membiayai investasi fixed asset serta investasi. Apabila secara berturut-turut terjadi defisit modal pada perusahaan, sehingga berakibat perusahaan menderita situasi financial distress. Berdasarkan pernyataan tersebut, dapat dikatakan CAR memiliki pengaruh yang negatif terhadap peluang perusahaan akan mengalami terjadinya financial distress yaitu nilai CAR yang tinggi dapat menjadi indikator terjadinya financial distress semakin kecil pada suatu bank. Namun, hasil tersebut tidak sejalan dengan Aminah (2019) dan (Febriana, 2019) CAR tidak berpengaruh signifikan terhadap financial distress pada bank karena bank selalu mengatur modal supaya tidak terjadi penurunan aset yang timbul akibat dari asset yang bermasalah.

H1 : Variabel permodalan memiliki pengaruh yang negatif terhadap probabilitas terjadinya financial distress.

Ismawati \& Istria (2015), mengemukakan kualitas asset berhubungan dengan resiko kredit yang bank hadapi ketika kredit yang sudah diberikan serta portofolio bank yang berbeda. NPL adalah rasio dari jumlah kredit yang diberikan serta nilai kolektibilitas. Iswanto (2018), jika variabel NPL meningkat maka probabilitas kebangkrutan bank juga akan mengalami peningkatan. Berdasarkan hasil penelitian terdahulu, dapat dinilai NPL menghasilkan hubungan yang positif apabila rasio NPL mendapatkan hasil yang tinggi bisa menjadi indikator adanya kredit yang bermasalah pada bank sehingga akan terjadi penurunan laba yang menyebabkan bank menderita financial distress. Hal tersebut dibantah oleh Theodorus \& Artini (2018) dan Pristianti \& Musdholifah (2020) yang mengemukakan NPL tidak berpengaruh terhadap probabilitas financial distress sebab kredit merupakan salah satu aspek dari total kekayaan. Sumber pendapatan bank banyak ditopang oleh asset produktif yang lain tidak hanya kredit. Selama Asset produktif bank mengalami peningkatan, maka tingginya NPL tidak signifikan dalam memengaruhi terjadinya financial distress.

H2: Variabel kualitas asset memiliki pengaruh yang positif terhadap probabilitas terjadinya financial distress.

Ismawati \& Istria (2015), menyatakan rasio BOPO yang tinggi, berarti bank tersebut kurang efisien dalam penggunaan pendapatan operasional untuk keperluan biaya operasionalnya, kemungkinan financial distress yang terjadi pada bank semakin tinggi. Menurut Sofiasani \& Gautama (2016), 
BOPO digunakan untuk mengukur nilai management efficiency yang berpengaruh kepada financial distress. Dapat menggambarkan bank yang memiliki biaya operasional yang terlampaui tinggi karena kesanggupan bank untuk mengelola rendahnya kegiatan operasionalnya, bisa memiliki pengaruh kepada tingkat efisiensi perbankan dan bank dapat menghasilkan keuntungan bersih (net income) yang maksimal. Berdasarkan hal tersebut rasio BOPO mempunyai keterkaitan yang positif apabila rasio nilai BOPO yang meningkat mengindikasikan pihak manajemen bank yang kurang mampu dalam mengondisikan pendapatan operasional terhadap biaya operasional yang mengakibatkan penurunan profitabilitas serta menimbulkan terjadinya financial distress. Pernyataan tersebut tidak sesuai dengan penelitian Africa (2018) dan Febriana (2019) mengemukakan BOPO tidak berpengaruh signifikan terhadap financial distress karena perbankan di Indonesia berada di batas maksimal BOPO yaitu $<95 \%$ berdasarkan surat edaran Bank Indonesia tanggal 31 Mei 2004 bernomor 6/23/dnp.

H3: Variabel manajemen memiliki pengaruh yang positif terhadap probabilitas terjadinya financial distress.

Sofiasani \& Gautama (2016), mengemukakan tingginya nilai ROA menunjukkan bank mampu mengelola aset secara efisien serta efektif hingga memeroleh target yang sesuai tingkat pengembalian sehingga bank mendapat tingkat laba yang maksimal. Bank yang memiliki nilai ROA cenderung mengalami penurunan yang bernilai negatif terdapat kemungkinan bank akan menderita terjadinya financial distress. Rasio ROA menghasilkan keterkaitan secara negatif kepada terjadinya financial distress pada bank. Berarti, nilai ROA yang tinggi mengindikasikan sangat efektifnya pengelolaan aset pada perusahaan akan berakibat ada probabilitas mengalami financial distress akan berkurang (Andari \& Wiksuana, 2017). Berdasarkan hasil penelitian tersebut, dapat dinilai bahwa ROA menghasilkan pengaruh negatif kepada terjadinya probabilitas financial distress yaitu nilai rasio ROA yang tinggi pada bank maka terjadinya probabilitas financial distress akan mengecil. Hal tersebut tidak sejalan Africa (2019) dan Sadida (2018) karena besarnya hasil ROA tidak selalu menunjukkan banyaknya keuntungan yang didapatkan menjamin terselamatkannya bank dari financial distress.

H4 : Variabel earning memiliki pengaruh yang negatif terhadap probabilitas terjadinya financial distress.

Sofiasani \& Gautama (2016), mengemukakan jika dalam bank menderita permasalahan pada likuiditas, hal tersebut akan berakibat bank sehingga mengalami kesulitan keuangan serta apabila bank tidak mengambil keputusan secara tepat sehingga mengakibatkan kebangkrutan. Maka, nilai rasio LDR yang kecil maka mengalami likuiditas pula, karena dana yang ada pada pihak ketiga tidak semuanya ditempatkan dalam bentuk kredit maka bank perlu mempunyai cadangan kas dalam mengumpulkan sumber likuiditas. Bank memiliki rasio LDR mempunyai nilai berkategori baik membuat terhadinya pendapatan bunga bank mengalami peningkatan, maka bank bisa terhindar dari kondisi sulit. Kurniasari \& Ghozali (2013), tingginya perbandingan LDR menghasilkan kesanggupan likuiditas bank yang rendah bisa membuat bank akan menderita kesulitan dalam keuangan. Berdasarkan hasil penelitian terdahulu dapat dinilai LDR mempunyai pengaruh secara positif kepada peluang terjadinya financial distress pada perbankan yang ditunjukkan dari rasio LDR yang tinggi , maka kemungkinan terjadinya financial distress juga semakin tinggi. Hasil tersebut dibantah oleh Africa (2018) dan Aminah (2019) LDR tidak berpengaruh signifikan terhadap financial distress karena dalam penelitiannya turun dan naiknya tingkat LDR tidak berpengaruh terhadap kondisi financial distress.

H5 : Variabel likuiditas memiliki pengaruh yang positif terhadap probabilitas terjadinya financial distress.

Baselga-Pascual et al. (2015), mengemukakan kondisi makroekonomi yang baik ditandai dengan adanya peningkatan pertumbuhan PDB riil maka akan memperkecil kemungkinan terjadinya risiko default dari para kreditur sehingga mengindikasikan mengalami financial distress pada lembaga keuangan akan menurun. Nilai PDB riil yang mengalami pertumbuhan bisa mengakibatkan terjadinya 
financial distress menurun. Nilai PDB riil yang rendah pertumbuhannya bisa diindikasikan terjadinya aktivitas ekonomi yang turun baik pada sektor riil maupun sektor keuangan. Peningkatan yang terjadi memungkinkan bank mengalami financial distress. Penurunan pertumbuhan yang terjadi pada sektor riil, disebabkan menghambatnya proses produksi sehingga dapat berpengaruh untuk sektor perbankan karena lembaga keuangan mempunyai fasilitas pelayanan kredit. Berdampak dalam sektor perbankan yang dapat dilihat dari kemungkinan default dalam fasilitas kredit yang ada dalam bank pada sektor riil. Berdasarkan hal tersebut GDP dapat mempunyai pengaruh secara negatif kepada peluang bank mengalami financial distress yang dihasilkan melalui pertumbuhan GDP yang tinggi dalam suatu negara, maka semakin kecil pula bank mengalami financial distress. Pernyataan tersebut tidak sejalan dengan Prianti (2018) dan Febriana (2019) sebab perubahan faktor makroekonomi pada negara tersebut akan sedikit atau banyak berpengaruh terhadap kebijakan yang akan diambil oleh lembaga perbankan.

H6 : Variabel makroekonomi yang diproksikan dengan GDP/PDB memiliki pengaruh yang negatif terhadap probabilitas terjadinya financial distress.

Baselga-Pascual et al. (2015), mengemukakan adanya laju inflasi yang meningkat menjelaskan perekonomian secara umum pada negara, jika bank tidak mampu dalam mengambil langkah maka akan berkibat pada nilai rasio NPL yang meningkat. Caggiano et al. (2014), tingginya inflasi berkaitan terhadap kondisi ekonomi yang tidak setabil sehingga berakibat pada nilai pengembalian aset (return on assets). Ditunjukkan bahwa terjadinya tingkat pinjaman yang menurun dan tingkat tabungan disebabkan suku bunga yang mengalami peningkatan. Inflasi serta suku bunga berhubungan dengan positif dan linier maka keputusan moneter bank sentral berguna mengatur stabilitas ekonomi salah satunya adalah suku bunga acuan. Maka, laju inflasi yang tinggi dalam suatu negara dapat berdampak pada bank sehingga mengalami financial distress. Berdasarkan hasil tersebut bisa dijelaskn bahwa tingkat inflasi mempunyai pengaruh secara positif terhadap peluang bank mengalami financial distress jika dilihat dari laju inflasi yang semakin tingi pada suatu negara , maka pada bank tersebut kemungkinan besar menderita financial distress. Hal tersebut dibantah oleh Febriana (2019) dan Wulandari et al. (2017) karena setiap adanya perubahan pada faktor makroekonomi suatu negara kebijakan lembaga perbankan akan berubah untuk mengambil keputusan yang akan menyelamatkan bank dari kondisi financial distress.

H7 : Variabel makroekonomi yang diproksikan dengan Inflasi memiliki pengaruh yang positif terhadap probabilitas terjadinya financial distress.

\section{METODE PENELITIAN}

Penelitian ini merupakan penelitian kausalitas, menguji pengarih variabel rasio CAMEL (CAR, NPL, BOPO, ROA dan LDR) dan variabel faktor makroekonomi (GDP dan Inflasi) terhadap variabel financial distress. Teknik pengumpulan data yang dipakai yaitu teknik dokumentasi berupa data sekunder melihat laporan keuangan tahunan BUSN non devisa. Sumber diambil dari internet yaitu melalui website BUSN non devisa yang resmi pada periode selama tahun 2014 hingga 2019. Populasi yang dipakai berasal dari seluruh BUSN non devisa yang telah menjadi anggota di Otoritas Jasa Keuangan dengan jumlah 30 bank. Penentuan sampel menggunakan teknik purposive sampling. Ketentuan pada sampel yang akan diambil penelitian ini yaitu Bank Umum Swasta Nasional Non Devisa yang sudah melaporan rekap keuangan tahunan (annual report) dalam periode 2014-2019, dan tidak termasuk Bank Syariah. Pada penelitian ini diambil sampel yang sesuai dengan kriteria sebanyak 20 bank. Uji hipotesis pada penelitian ini memakai analisis regresi logistik yang dapat mengolah teknik analisis data, disebabkan mempunyai satu variabel dependent yang non metrik (nominal) dan mempunyai variabel independent lebih dari satu maka tidak perlu adanya asumsi normalitas data pada variabel bebasnya (Ghozali, 2018). Perhitungan analisis regresi logistik menggunakan bantuan Program SPSS 25 pada saat mengolah data. Data yang akan dianalisis akan menghasilkan yaitu menilai model fit, koefisien determinasi, uji kelayakan model, uji keakuratan regresi, serta uji estimasi parameter. 
HASIL DAN PEMBAHASAN

TABEL 1.

MODEL SUMMARY

\begin{tabular}{|c|c|c|c|c|}
\hline Step & $\begin{array}{c}-2 \log \\
\text { likelihood }\end{array}$ & $\begin{array}{l}\text { Cox \& Snell } \\
\text { Rsquare }\end{array}$ & Nagelkerke Rsquare & Hosmer and Lemeshow Test \\
\hline 0 & 58,783 & 0,156 & 0,403 & 0,182 \\
\hline 1 & 38,429 & & & \\
\hline
\end{tabular}

Sumber: Output SPSS (2021, data diolah)

\section{Menilai Model Fit}

Tabel 1, nilai -2 Log Likehood (-2LogL) yaitu 58,783. Dapat dikatakan model yang hanya memasukkan konstanta saja sebesar 58,783 yaitu signifikan pada alpha $<0,05(58,783<145,461)$ maka model yang menggunakan konstanta saja sudah fit dengan data yang ada. Nilai -2 Log Likehood (-2LogL) pada model yang memasukkan variabel sebesar 38,429. Model yang memasukkan variabel sebesar 38,429, signifikan pada alpha <0,05 $(38,429<137,701)$ sehingga model fit dengan data.

\section{Koefisien Determinasi}

Tabel 1 model summary memerlihatkan besarnya pengaruh model terhadap peluang terjadinya financial distress. Nagelkerke $R$ Square menghasilkan nilai 0,403. Nilai tersebut menjelaskan bahwa besaran pengaruh variabel independen (CAR, NPL, BOPO, ROA, LDR, GDP dan Inflasi) dalam menjadi indikator terjadinya financial distress dalam penelitian ini yaitu sebesar 0,403 atau 40,3\% selanjutnya sisanya yaitu 59,7\% dipengaruhi dari faktor lain di luar variabel penelitian ini.

\section{Uji Kelayakan Model}

Nilai signifikansi yang dihasilkan Hosmer and Lemeshow's test adalah 0,182 (nilai Hosmer and Lemeshow's test >0,05). Model prediksi yang didapat cocok atau fit dengan data observasi. Maka model mampu menjadi gambaran nilai observasi atau diterima sesuai dan cocok, selanjutnya dapat dilakukan uji hipotesis pada setiap variabel independen.

Tabel 2.

HASIL ANALISIS UJI KETEPATAN PREDIKSI MODEL REGRESI

\begin{tabular}{ccccccc}
\hline & Observed & & \multicolumn{3}{c}{ Predicted } \\
& & & $\mathbf{0 0}$ & $\mathbf{1 , 0 0}$ & $\begin{array}{c}\text { Percentage } \\
\text { Correct }\end{array}$ \\
\hline Step 1 & $\mathrm{Y}$ &, 00 & 110 & 2 & 98,2 \\
& & 1,00 & 6 & 2 & 25,0 \\
& \multicolumn{2}{c}{ Overall Percentage } & & & 93,3 \\
\hline
\end{tabular}

Sumber: Output SPSS (2021, data diolah)

\section{Uji Ketepatan Prediksi Model Regresi}

Ketepatan prediksi model regresi logistik merupakan perhitungan estimasi yang benar dan salah. Dapat dilihat bahwa hasil analisis pada tabel 2 terdapat nilai yang memprediksi variabel dependen (financial distress) umtuk menjelaskan kondisi bank sehat atau non-distress (0) dan kondisi bank yang tidak sehat atau distress (1). Sebanyak 112 bank yang mengalami non financial distress yang sudah dianalisis di mana 110 bank diprediksi tidak menderita financial distress sedangkan 2 bank menderita financial distress, dengan tingkat keakuratan sebesar 98,2\%. Selanjutnya, diketahui terdapat 8 sampel bank dengan 6 bank tidak menderita financial distress dan 2 bank menderita financial distress di mana keakurasiannya dengan hasil $25 \%$. Hasil model prediksi dalam penelitian dengan nilai di atas 0,05. 
Wella Wahyu Qur'anna \& Yuyun Isbanah. Pengaruh Rasio Camel dan Faktor Makroekonomi terhadap Kondisi Financial Distress pada Bank Busn Non Devisa tahun 2014-2019

Artinya, keseluruhan tingkat akurasi model prediksi menggunakan analisis CAMEL/Makroekonomi untuk menilai kondisi bank mengalami distress atau tidak sebesar 93,3\%.

Tabel 3.

HASIL ANALISIS REGRESI

\begin{tabular}{llcrrr}
\hline & & Score & Df & \multicolumn{1}{c}{ Sig. } \\
\hline Step 1 & Variables & CAR & .044 & 1 & .833 \\
& NPL & .000 & 1 & .987 \\
& BOPO & .000 & 1 & .995 \\
& ROA & .200 & 1 & .000 \\
& LDR & .263 & 1 & .608 \\
& GDP & .207 & 1 & .650 \\
& Inflasi & .733 & 1 & .392 \\
& Constanta & .508 & 1 & .000 \\
\hline Sumber: Output SPSS (2021, data diolah) & & &
\end{tabular}

Sumber: Output SPSS (2021, data diolah)

Berdasarkan tabel 3, variabel independen yang signifikan adalah Return On Asset (ROA), pada variabel ROA dengan nilai signifikan $\alpha 0,05$ yaitu sebesar 0,00 . Dilihat dari hasil persamaan regresi logistik bisa menunjukkan bahwa ROA berpengaruh secara negatif terhadap log odds financial distress, apabila diasumsikan variabel yang lain konstan maka semakin kecil nilai ROA akan menyebabkan probabilitas terjadinya financial distress meningkat dengan faktor $\left(\mathrm{e}^{-0,712}\right)$ untuk setiap penurunan satu unit Return on Asset (ROA).

Berdasarkan anasilis uji hipotesis dapat dilihat variabel yang tidak mempunyai pengaruh terhadap financial distress, merupakan variabel yang menghasilkan taraf signifikansi yang lebih besar dari nilai $\alpha$ 0,05. Maka variabel yang tidak memengaruhi financial distress adalah variabel permodalan yang diproksikan dengan CAR, variabel kualitas aset yang diproksikan dengan NPL, variabel manajemen yang diproksikan dengan BOPO, variabel likuiditas yang diproksikan dengan LDR, variabel makroekonomi yang diproksikan dengan GDP, variabel makroekonomi yang diproksikan dengan Inflasi.

\section{Pengaruh Variabel Permodalan terhadap Financial Distress}

Variabel permodalan yang diproksikan dengan CAR, diketahui CAR tidak berpengaruh terhadap peluang terjadinya financial distress pada bank BUSN non devisa. Hasil tersebut menunjukkan bahwa tidak adanya pengaruh variabel CAR terhadap financial distress tidak sependapat dari teori model generasi kedua yaitu faktor internal pada perbankan memengaruhi terjadinya financial distress. Maka dari itu, teori tersebut menjelaskan kesulitan keuangan atau financial distress bisa juga dipengaruhi oleh faktor internal yang lain yang ada pada lembaga keuangan. Hasil analisis tersebut tidak sependapat dengan Sadida (2018), CAR dapat digunakan sebagai prediktor terjadinya financial distress pada bank. Sejalan dengan pernyataan tersebut dari (Prianti, 2018), rasio CAR akan menunjukkan probabilitas terjadinya financial distress pada bank.

Modal bank yang turun akan mengindikasikan bahwa bank tersebut mengalami kesulitan keuangan, lain dari hal tersebut rasio CAR yang menurun menyebabkan bank untuk menanggung resiko kerugian. Sehingga, akan meningkatkan peluang terjadinya kebangkrutan pada bank (Halim, 2016). Namun dari hal tersebut dapat dilihat, nilai rataan CAR pada BUSN non devisa di atas batasan sebesar $8 \%$ yang menunjukkan terdapat dalam batas aman. Berdasarkan data yang sudah dikumpulkan, menunjukkan Bank Harda Internasional tahun 2019 termasuk bank yang menderita financial distress tetapi menghasilkan nilai CAR sebesar 16,2\%. Hal yang sama terjadi pada Bank Artos Indonesia tahun 2016 sampai 2018 memiliki rata-rata nilai CAR sebesar 20,57\% namun tergolong bank yang menderita financial distress. Hasil penelitian (Febriana, 2019) tingginya nilai CAR namun bank tergolong financial distress menunjukkan CAR tidak berpengaruh terhadap financial distress 
disebabkan CAR perbankan di Indonesia sudah sesuai dengan standar minimal kepemilikan modal dilihat dari ketentuan Bank Indonesia. Hasil penelitian ini sejalan dengan Aminah (2019), lembaga perbankan kebanyakan sanggup dalam mengatur modalnya maka bank tidak sampai menderita harta yang menyusut karena timbul harta yang bermasalah.

\section{Pengaruh Variabel Kualitas Aset terhadap Financial Distress}

Variabel NPL tidak memiliki pengaruh terhadap terjadinya financial distress dalam bank BUSN non devisa. Hal tersebut sejalan dengan penelitian dari Andari \& Wiksuana (2017), NPL tidak memiliki pengaruh secara signifikan dalam mengindikasi bank mengalami financial distress. Selain itu, nilai rataan NPL dari BUSN non devisa tidak melanggar batas yang sudah ditetapkan yaitu sebesar 5\% yang menunjukkan dalam kategori batas aman. Salah satu bank yang mengalami financial distress adalah Oke Bank pada tahun 2014 hingga 2016 padahal mempunyai nilai rataan NPL sebesar 0,48\%. Hasil yang sama juga dialami oleh Bank Artos Indonesia yang memiliki NPL tahun 2019 sebesar $0,21 \%$ namun tetap tergolong bank yang mengalami financial distress. Hal tersebut sejalan dengan Theodorus \& Artini (2018), meningkatnya NPL belum bisa dikatakan sebagai prediktor terjadinya probabilitas financial distress. Berbeda dengan teori model generasi kedua yaitu faktor internal pada lembaga perbankan dapat menimbulkan financial distress. Maka dari itu, kesulitan keuangan atau financial distress bisa juga dipengaruhi oleh faktor internal yang lain yang ada pada bank. Hasil analisis pada variabel NPL yang tidak berpengaruh menunjukkan adanya pertentangan dengan penelitian sebelumnya dari Ismawati \& Istria (2015), bahwa variabel NPL yang memiliki pengaruh secara positif kepada peluang terjadinya financial distress.

\section{Pengaruh Variabel Manajemen terhadap Financial Distress}

Variabel manajemen yang diproksikan dengan BOPO tidak berpengaruh secara signifikan untuk memprediksi bank BUSN non devisa yang kan mengalami financial distress. Hasil tersebut menunjukkan tidak adanya pengaruh variabel BOPO terhadap financial distress tidak sependapat dengan teori model generasi kedua yaitu faktor internal pada bank akan mengalami financial distress. Terlihat pada Bank Victoria dan Bank Sahabat Sampoerna tahun 2019 memiliki rasio BOPO sebesar 100,69\% dan 96,49\% yang lebih besar dari ketetapan Bank Indonesia yaitu 95\%, namun tidak tergolong bank yang mengalami financial distress. Berarti financial distress tidak disebabkan oleh tingginya rasio BOPO. Hal tersebut dapat terjadi karena bank mampu memperoleh pendapatan bunga yang optimal dan menekan kredit yag bermasalah, tidak berpengaruhnya rasio BOPO kepada financial distress sejalan dengan Ramadhani (2019) dan Nufus et al. (2018). Maka dari itu, teori tersebut menjelaskan bahwa kesulitan keuangan atau financial distress bisa juga dipengaruhi oleh faktor internal yang lain yang ada pada bank. Sejalan dengan hasil penelitian dari Kurniasari \& Ghozali (2013), rasio BOPO dengan nilai tinggi bisa menyebabkan bank mengalami financial distress. Rasio BOPO yang menghasilkan hubungan positif mencerminkan ketidakmampuan manajemen bank dalam mengatur pendapatan operasional dalam melakukan pembiayaan operasional yang mengakibatkan terjadinya financial distress.

\section{Pengaruh Variabel Earning terhadap Financial Distress}

Variabel ROA memiliki pengaruh terhadap prediksi terjadinya financial distress pada bank BUSN non devisa. Pengaruh dari variabel ROA terhadap financial distress sependapat dengan teori model generasi kedua yaitu faktor internal pada bank bisa memengaruhi financial distress (Obstfeld, 1984). Terbukti pada bank yang mengalami financial distress seperti pada Bank Artos Indonesia, Bank Harda Internasional pada tahun 2019 yang masing-masing memiliki ROA sebesar -15,89\% dan 1,87\%, selain itu Oke Bank tahun 2016 memiliki ROA sebesar $-1,82 \%$. Hal tersebut menunjukkan kesanggupan bank yang kurang dalam mengelola aset secara efesien dan efektif maka akan berdampak pada pengembalian yang minimum sehingga berakibat laba yang didapat oleh bank kurang maksimal (Sofiasani \& Gautama, 2016). Bank BTPN dan Fama Internasional pada tahun 2019 memiliki ROA masing-masing sebesar $2,3 \%$ dan $1,67 \%$ yang telah melebihi dari batas minimal ditetapkan BI sebesar 1,5\% dan tidak tergolong dalam bank yang mengalami financial distress. Hasil analisis variabel ROA yang berpengaruh secara negatif signifikan sejalan dengan penelitian dari Iswanto (2018), hasil rasio ROA yang mengalami peningkatan sebesar satu satuan maka kemungkinan 
Wella Wahyu Qur'anna \& Yuyun Isbanah. Pengaruh Rasio Camel dan Faktor Makroekonomi terhadap Kondisi Financial Distress pada Bank Busn Non Devisa tahun 2014-2019

mengalami financial distress akan menurun. Sejalan dengan penelitian Andari \& Wiksuana (2017), rasio ROA memiliki hubungan negatif kepada financial distress pada bank. Maka, variabel ROA mempunyai pengaruh secara negatif terhadap probabilitas bank mengalami financial distress yaitu tingginya rasio ROA dari suatu bank maka peluang semakin kecil bank mengalamil financial distress.

\section{Pengaruh Variabel Likuiditas terhadap Financial Distress}

Variabel LDR tidak berpengaruh dalam memprediksi terjadinya financial distress pada bank BUSN non devisa. Berdasarkan hal tersebut maka tidak adanya pengaruh pada variabel LDR terhadap financial distress tidak sependapat dengan teori model generasi kedua yaitu faktor internal memengaruhi terjadinya financial distress pada bank (Obstfeld, 1984). Terbukti pada bank Artos Indonesia tahun 2017 tergolong bank yang menderita financial distress, namun menghasilkan nilai LDR sebesar 72,68\% yang tergolong sangat sehat karena tidak melebihi batas ketetuan BI yaitu sebesar $75 \%$. Selain itu, pada bank Harda Internasional yang tergolong lembaga keuangan yang menderita financial distress juga menghasilkan rataan nilai LDR di bawah $100 \%$ yang tergolong cukup sehat karena batas maksimal yang ditentukan BI adalah 100\%. Sesuai dengan penelitian Aminah (2019), bahwa penurunan serta peningkatan pada LDR dalam periode tahun 2014 sampai 2019 tidak memengaruhi tingkat financial distress pada bank. Sejalan dengan teori tersebut rasio LDR yang tinggi menjelaskan kemampuan likuiditas bank yang rendah dapat berakibat terjadinya financial distress (Kurniasari \& Ghozali, 2013). Sedangkan, Sofiasani \& Gautama (2016), menjelaskan bahwa bank yang mengalami krisis likuiditas, kemungkinan bank tersebut mengalami financial distress.

\section{Pengaruh Variabel Makroekonomi yang Diproksikan dengan GDP terhadap Financial Distress} Variabel GDP tidak berpengaruh dalam memprediksi bank BUSN non devisa mengalami financial distress. Hasil yang tidak berpengaruh pada variabel GDP terhadap financial distress tidak sejalan dengan teori model generasi pertama yaitu faktor makroekonomi pada bank memengaruhi terjadinya financial distress. Tingkat GDP selama tahun 2014 sampai dengan 2019 mengalami fluktuasi, pada tahun 2015 dan 2019 tingkat GDP di Indonesia mengalami penurunan masing-masing sebesar 4,79\% dan 5,02\% yang mengalami penurunan dibandingkan tahun sebelumnya. Akan tetapi, tidak semua bank mengalami kesulitan keuangan yang diakibatkan oleh turunnya GDP tersebut. Sebaliknya tahun 2018 tingkat GDP mencapai 5,17\% yang tergolong tinggi dibandingkan tahun sebelumnya, namun masih terdapat bank yang mengalami financial distress yaitu Bank Artos Indonesia. Selain itu, pemerintah akan menetapkan sebuah kebijakan untuk mendorong pertumbuhan GDP yang akan melindungi industry perbankan (Prianti, 2018). Dari hasil tersebut bahwa financial distress atau kesulitan keuangan bisa juga dipengaruhi dari faktor makroekonomi yang ada pada suatu negara. Sejalan dengan hal tersebut Wulandari et al. (2017), pertumbuhan PDB riil yang rendah menunjukkan kemungkinan terjadinya financial distress. Sedangkan, Baselga-Pascual (2015), kondisi makroekonomi yang baik akan meningkatkan terjadinya financial distress.

\section{Pengaruh Variabel Makroekonomi yang Diproksikan dengan Inflasi terhadap Financial Distress}

Variabel inflasi tidak berpengaruh dalam memprediksi bank BUSN non devisa mengalami financial distress. Hasil tersebut menjelaskan bahwa tidak berpengaruh pada variabel inflasi terhadap financial distress tidak sejalan dengan teori model generasi pertama dan Mahmood et al. (2014), yaitu faktor makroekonomi khusunya laju inflasi memengaruhi terjadinya financial distress pada bank. Di Indonesia tingkat inflasi selama tahun 2015 hingga 2018 rata-rata berada pada angka 3\% yang merupakan ketentuan laju inflasi yang ideal bagi Indonesia dalam jangka waktu menengah maupun jangka panjang (Kunjana, 2017). Bahkan, tahun 2019 tingkat inflasi Indonesia sebesar 2,72\% yang tidak melebihi batas ketentuan, namun masih terdapat bank yang mengalami financial distress yaitu Bank Harda Internasional dan Bank Artos Indonesia. Berubahnya keadaan makroekonomi suatu negara dapat memberi efek terhadap keputusan industri yang mampu memengaruhi kebijakan perbankan dihasilkan pihak dalam bank perlu beradaptasi terhadap laju inflasi yang bertumbuh dengan melakukan pemangkasan suku bunga pinjaman maka akan mampu memacu iklim investasi (Prianti, 2018). Berdasarkan penelitian Caggiano et al. (2014), tingginya inflasi yang terjadi memiliki keterkaitan terhadap ketidakstabilan kondisi ekonomi, sehingga menyebabkan terjadinya financial distress. Sejalan dengan Musdholifah et al. (2020), bahwa laju inflasi yang tinggi akan berhubungan 
dengan tingginya nilai suku bunga menyebabkan kerugian pada perekonomian pada suatu negara, sehingga menyebabkan terjadinya financial distress.

\section{KESIMPULAN}

Kesimpulan penelitian ini, financial distress dipengaruhi oleh variabel earning yang diproksikan dengan ROA sebab menghasilkan pengaruh negatif terjadinya probabilitas financial distress yaitu nilai rasio ROA yang tinggi pada bank maka terjadinya probabilitas financial distress akan mengecil. Selain dari variabel ROA terdapat variabel lain yaitu permodalan yang diproksikan dengan CAR tidak berpengaruh signifikan terhadap financial distress pada bank karena bank selalu mengatur modal supaya tidak terjadi penurunan aset yang timbul akibat dari asset yang bermasalah. Kualitas Aset yang diproksikan dengan NPL tidak berpengaruh karena selama aset produktif bank mengalami peningkatan, maka tingginya NPL tidak signifikan dalam mempengaruhi terjadinya financial distress. Manajemen yang diproksikan dengan BOPO tidak berpengaruh terhadap financial distress karena perbankan di Indonesia berada di batas maksimal BOPO yaitu < $95 \%$ berdasarkan surat edaran Bank Indonesia tanggal 31 Mei 2004 bernomor 6/23/dnp. Likuiditas yang diproksikan dengan LDR tidak berpengaruh terhadap financial distress karena turun dan naiknya tingkat LDR. tidak berpengaruh terhadap kondisi financial distress. Faktor makroekonomi yang diproksikan dengan GDP dan Inflasi yang tidak memiliki pengaruh signifikan terhadap probabilitas terjadinya financial distress pada bank BUSN non devisa Tahun 2014-2019 karena setiap adanya perubahan pada faktor makroekonomi suatu negara kebijakan lembaga perbankan akan berubah untuk mengambil keputusan yang akan menyelamatkan bank dari kondisi financial distress. Maka, rasio ROA dapat menjadi penyebab financial distress perbankan pada bank BUSN non devisa Tahun 2014-2019.

Upaya pencegahan financial distress perbankan mengharuskan pihak manajemen bank untuk lebih meningkatkan rasio ROA. Rasio ROA dapat digunakan untuk mengatasi financial distress pada bank, dengan cara meningkatkan keuntungan bank. Adanya peningkatan keuntungan menandakan operasional usaha dari suatu bank yang berjalan baik. Sebagai nasabah bank, hendaknya untuk selalu menyelesaikan kewajiban pada bank dengan baik, menggunakan produk bank sesuai kebutuhan. Keterbatasan penelitian ini, pertama, yang digunakan hanya terbatas sebanyak 20 bank. Kedua, periode penelitian hanya enam tahun mulai tahun 2014 sampai 2019. Dengan proses pengamatan yang lebih panjang dapat memungkinkan memeroleh terjadinya peluang financial distress yang tepat dan akurat. Ketiga, variabel penelitian yang dipakai pada penelitian ini berjumlah tujuh variabel antara lain CAR, NPL, BOPO, ROA, LDR, GDP dan Inflasi. Oleh karena itu, penelitian ini belum dapat digunakan untuk mendeteksi financial distress pada bank karena masih terdapat $59,7 \%$ yang mengindikasikan masih terdapat faktor lain di luar variabel penelitian yang diduga mampu memengaruhi financial distress pada bank. Selain itu, variabel independen yang digunakan dalam penelitian ini masih terdapat variabel independen yang tidak berpengaruh signifikan terhadap variabel dependen. Sehingga, diperlukan adanya penggunaan variabel independen lain, baik dari faktor internal bank, faktor makroekonomi, dan faktor lain yang masih berkaitan bertujuan agar variabel independen terhadap variabel dependen dapat lebih akurat dalam mendeteksi terjadinya financial distress pada bank. Dari keterbatasan dalam penelitian tersebut, maka saran bagi penelitian yang akan datang agar mengambil sampel penelitian yang lebih banyak, mempertimbangkan kualitas perusahaan, serta variasi perbankan devisa atau non devisa. Kemudian, penelitian selanjutnya bisa memperpanjang periode waktu penelitian dan menambah variabel yang tidak digunakan dalam penelitian ini untuk memeroleh hasil yang lebih akurat.

\section{DAFTAR PUSTAKA}

Africa, L. A. (2018). Bankometer Models for Predicting Financial distress in Banking Industry. Jurnal Keuangan Dan Perbankan, 22(2), 373-379. https://doi.org/10.26905/jkdp.v22i2.2050

Africa, L. A. (2019). Financial Distress Prediction Using RGEC Model on Foreign Exchange Banks and Non-Foreign Exchange Banks. Journal of Accounting and Strategic Finance, 2(1), 48-55. 
Wella Wahyu Qur'anna \& Yuyun Isbanah. Pengaruh Rasio Camel dan Faktor Makroekonomi terhadap Kondisi Financial Distress pada Bank Busn Non Devisa tahun 2014-2019

https://doi.org/10.33005/jasf.v2i1.34

Africa, L. A. (2018). Bankometer Models for Predicting Financial Distress in Banking Industry. Jurnal Keuangan dan Perbankan, 22(2), 373-379. https://doi.org/10.26905/jkdp.v22i2.2050

Africa, L. A. (2019). Financial Distress Prediction Using RGEC Model on Foreign Exchange Banks and Non-Foreign Exchange Banks. Journal of Accounting and Strategic Finance, 2(1), 48-55. https://doi.org/10.33005/jasf.v2i1.34

Amalia, N. I., \& Mardani, R. M. (2018). Analisis Rasio Keuangan Terhadap Financial Distress (Pada Perusahaan Perbankan Yang Listing Di BEI Periode Tahun 2014-2016). Jurnal Ilmiah Riset Manajemen, 7(9).

Aminah, S., Rizal, N., \& Taufiq, M. (2019). Pengaruh Rasio CAMEL terhadap Financial Distress pada Sektor Perbankan. Counting: Journal of Accounting, 2(1), 86-94.

Andari, N. M., \& Wiksuana, I. G. B. (2017). RGEC Sebagai Determinasi Dalam Menanggulangi Financial Distress Pada Perusahaan Perbankan Di Bursa Efek Indonesia. E-Jurnal Manajemen, 6(1), 116-145.

Andari, N., \& Wiksuana, I. (2017). Rgec Sebagai Determinasi Dalam Menanggulangi Financial Distress Pada Perusahaan Perbankan Di Bursa Efek Indonesia. E-Jurnal Manajemen, 6(1), $116-145$.

Anggraini, A. (2019). Perkembangan Fintech di Indonesia | Indonesia Baik. http://indonesiabaik.id/infografis/perkembangan-fintech-di-indonesia. Diakses 17 Februari 2021.

Bank Artos. (2020). BANK ARTOS - Home. http://www.bankartos.co.id/financialreport.html. Diakses 10 Februari 2021.

Bank Harda Internasional. (2019). Laporan Tahunan-2019. https://www.bankbhi.co.id/bhi/index.php/hubinvestor/laporan-keuangan/laporantahunan/laporan-tahunan-2019. Diakses 10 Februari 2021.

Bank Indonesia, O. B. I. (2020). OK! Bank Indonesia | Informasi Finansial. https://www.okbank.co.id/investor/financial?id=2. Diakses 2 Maret 2021.

Baselga-Pascual, L., Trujillo-Ponce, A., \& Cardone-Riportella, C. (2015). Factors influencing bank risk in Europe: Evidence from the financial crisis. The North American Journal of Economics and Finance, 34, 138-166.

Caggiano, G., Calice, P., \& Leonida, L. (2014). Early warning systems and systemic banking crises in low income countries: A multinomial logit approach. Journal of Banking \& Finance, 47, 258 269. https://doi.org/10.1016/j.jbankfin.2014.07.002

Febriana, S. I. (2019). Faktor-Faktor Yang Memengaruhi Perbankan Dalam Memprediksi Banking Distress Dengan Metode CD Indeks. Jurnal Ilmu Manajemen (JIM), 7(4).

Ghozali, I. (2018). Aplikasi Analisis Multivariete dengan Program IBM SPSS 25. Semarang: Badan Penerbit Universitas Diponegoro.

Halim, C. (2016). Analysis Effect Accounting Ratio and Market Effect to Predicting Bank's Bankruptcy with Logistic Regression Model. JOM Fekon, 3(1), 1294-1308. 
Ismawati, K., \& Istria, P. C. (2015). Detektor financial distress perusahaan perbankan indonesia. Jurnal Ekonomi Bisnis dan Kewirausahaan, 4(1), 6-29.

Iswanto, I. (2018). Memprediksi Kebangkrutan Perusahaan Perbankan (Studi Pada Perusahaan Perbankan Yang Tercatat di Bei). Manajemen Bisnis, 4(2). https://doi.org/10.22219/jmb.v4i2.5292

Kasmir. (2014). Manajemen Perbankan (12 ed.). Depok: Rajawali Press.

Kunjana, G. (2017). Inflasi Ideal RI 3\%. investor.id. https://investor.id/archive/inflasi-ideal-ri-3. Diakses tanggal 27 Maret 2021.

Kurniasari, C., \& Ghozali, I. (2013). Analisis pengaruh rasio CAMEL dalam memprediksi financial distress perbankan Indonesia. Fakultas Ekonomika dan Bisnis.

Letarisky, M. (2014). Pengaruh Indikator Fundamental Makroekonomi Terhadap Foreign Direct Investment di Indonesia. Jurnal Administrasi Bisnis (JAB), 15(2), 9.

Maharani, R. D. (2018). Determinan Keberhasilan Turnaround pada Perusahaan yang Mengalami Financial Distress Jurnal Bisnis dan Manajemen, 2(031), 130.

Mahmood, H., Waheed, A., \& Khalid, S. (2014). Role of macroeconomic indicators in banking crisis. Academic Research International, 5(2), 205.

Musdholifah, M., Hartono, U., \& Wulandari, Y. (2020). Banking crisis prediction: Emerging crisis determinants in Indonesian banks. International Journal of Economics and Financial Issues, 10(2), 124-131.

Nufus, K., Audina, N., \& Muchtar, A. (2018). Effect of Financial Distress Ratio Banking Company in Indonesia Period 2011-2015. Research Journal of Finance and Accounting, 8.

Nugroho, A. (2012). Faktor-Faktor yang Mempengaruhi Intellectual Capital Disclosure (ICD). Accounting Analysis Journal, 1(2).

Obstfeld, M. (1984). Rational and self-fulfilling balance-of-payments crises. The American Economic Review Vol. 76, No. 1 (Mar., 1986)

Otoritas Jasa Keuangan. (2016). Kredit Bermasalah Meningkat Periode 2013-2016 | Databoks. https://databoks.katadata.co.id/datapublish/2016/12/05/kredit-bermasalah-meningkat-periode2013-2016. Diakses tanggal 20 Februari 2021.

Paul, K. (1979). A model of balance of payments crises. Journal of Money, Credit and Banking, 11(3), 311-325.

Prasidha, D. K. (2015). Dampak Nilai Tukar dan Risk-Based Bank Rating Terhadap Prediksi Kondisi Perbankan Indonesia. Quantitative Economics Journal, 4(3).

Prianti, F. (2018). Pengaruh RGEC dan Variabel Makroekonomi terhadap Banking Distress dengan Menggunakan CD Indeks di Indonesia. Jurnal Ilmu Manajemen (JIM), 6(3).

Pristianti, R., \& Musdholifah, M. (2020). Pengaruh Risk Based Bank Rating terhadap Financial Distress dengan Bankometer Model Pada Busn Non Devisa. Jurnal Ilmu Manajemen, 8, 717 733. 
Wella Wahyu Qur'anna \& Yuyun Isbanah. Pengaruh Rasio Camel dan Faktor Makroekonomi terhadap Kondisi Financial Distress pada Bank Busn Non Devisa tahun 2014-2019

Ramadhani, U. (2019). Prediction Model of Financial Distress Based on Financial Performance of Conventional Go-Public Banks in Indonesia. Management and Economic Journal. 461, 14.

Rodoni, ahmad. (2014). Manajemen Keuangan Modern. Mitra Wacana Media.

Rosita, M., \& Musdholifah, M. (2018). Pengaruh Makroekonomi, Capital Adequacy Ratio, Loan To Deposit Ratio dan Pertumbuhan Kredit terhadap Non Performing Loan pada Bank Asing di Indonesia Periode 2013-2014. BISMA (Bisnis dan Manajemen), 8(2), 124-143.

Sadida, B. D. (2018). Risk Profile, Good Corporate Governance, Earnings, and Capital (RGEC) Sebagai Prediktor Terhadap Kondisi Financial Distress Pada Perusahaan Perbankan. Jurnal Manajemen Bisnis Indonesia (JMBI), 7(4), 347-357.

Santoso, S. indra. (2017). Pengaruh Laba, Arus Kas dan Corporate Governance terhadap Financial Distress (Studi pada Perusahaan Manufaktur yang Terdaftar di Bursa Efek Indonesia Periode 2011-2015). Al-Buhuts, 13(01), 01-22. https://doi.org/10.30603/ab.v13i01.428

Siregar, R. I., \& Fauzie, S. (2012). Analisis Manfaat Rasio Keuangan Ddalam Memprediksi Financial Distress Pada Perbankan (2007-2012). Jurnal ekonomi dan keuangan, 2(12), 14826.

Sitanggang, L. (2018). Meski naik, LDR BPD masih lebih rendah dibanding bank lain. kontan.co.id. http://keuangan.kontan.co.id/news/meski-naik-ldr-bpd-masih-lebih-rendah-dibanding-banklain. Diakses tanggal 4 Maret 2021.

Sofiasani, G., \& Gautama, B. P. (2016). Pengaruh CAMEL terhadap Financial Distress pada Sektor Perbankan Indonesia Periode 2009-2013. Journal of Business Management Education (JBME), l(1), 138-148. https://doi.org/10.17509/jbme.v1i1.2283

Theodorus, S., \& Artini, L. G. S. (2018). Studi Financial Distress pada Perusahaan Perbankan di BEI. $\begin{array}{llll}\text { E-Jurnal Manajemen Universitas } & \text { Udayana, }\end{array}$ https://doi.org/10.24843/EJMUNUD.2018.v07.i05.p16

Waluyo, D., \& Yulianti, U. (2016). Ekonomika Makro. Malang: UMM Press.

Wulandari, Y., Musdholifah, M., \& Kusairi, S. (2017). The Impact of Macroeconomic and Internal Factors on Banking Distress. International Journal of Economics and Financial Issues, 7(3), 429. 